\title{
SCIENCE AND GOVERNMENT REORGANIZATION IN BRITAIN
}

A SENTENCE in The Qucen's Speech at the opening of Parliament on November 3 stated that Britain's industries would be helped to gain the full benefits of advances in scientific research and applied technology. The Speech also announeed that central and regional plans were being prepared to promote economic development, with special reference to the needs of the underemployed areas of the country. New arrangements (including the appointment of a Secretary of State for Wales, with a seat in the Cabinet, and a Minister of State, Welsh Office) would ensure that proper attention would be directed to the needs of Wales, and legislation would be introduced to provide for the appointment of a Highland Development Authority. Some light was thrown on these and other changes in the structure of the Government in the subsequent debate on the address to the Throne, although early in the debate Sir Alec Douglas. Home was critical of certain changes, particularly the fragmentation of the Treasury and some Ministries, such as the Ministry of Education and Science. He believed that to take the Ministry of Technology out of the latter Ministry was a real mistake.

Mr. R. Maxwell, in a maiden speech, however, welcomed the new Ministry of Technology, and also supported the proposal to review the Concord project. He referred to the backwardness of much of British industry in making use of science and technology as an aid to increased productivity, and suggested that one of the major obstacles was ineffective communication at various levels-between scientist and technologist and management, between industry and Government, between universities, colleges of technology and research associations. Like Lord Thomson of Fleet, Lord Melchett and Lord Boothby, in the corresponding debate in the House of Lords on November 5, he also emphasized the special importance of management. Lord Melchett, while agreeing as to the importance of efficient management and the structure of labour and management relations, questioned whether the establishment of a Department of Economic Affairs and a Ministry of Technology would do more than shift the emphasis and priorities within a system incap. able of satisfactory rates of sustained growth. Nor did he think that the proposals for economic planning, the stimulation of science and technology, and the correction of assumed errors in past policies went to the roots of the matter. Mr. Maxwell, however, urged that the strength of our science depended on the initiative, imagination and intelligence of individual scientists and engineers, and thought that the Government's arrangements for organizing science and technology would meet the need.

Speaking in the debate on November 4, the Secretary of State for Economic Affairs, Mr. G. Brown, recognized the value of the work of the National Economic Development Council and said that it was the intention of the Department of Economic Affairs to take up the work of that Council, expand and develop it, and produce, in consultation with both sides of industry, through the Council, a plan for the next five years to guide the development of the economy and all the economic activities of the Government. Under the new policy the responsibility must be with the Government and in future this planning would be carried out in the Department of Economic Affairs, in close co-operation with the Treasury and other Departments concerned. Part of the staff of the Couneil's office had already joined his Department for this purpose, but there was a continuing need for an outside body. It was proposed to reconstitute the Council on mueh the same lines as it was based before with a membership of about twenty from Government, management and Trade Unions, with some independent members.
Sir Robert Shone had been invited to continue as directorgencral. He thought that the regional councils would grow in importance and he was proposing that they should work in closer association with the Department of Economic Affairs and other Departments.

Mr. Brown then stated that the Government's regional economic plans would take their place within a coherent national framework, and effective means for consultation would be set up in the regions. The first major task was to fashion the national framework into which the detailed work of the regional investigations would fit, and this was one reason why the Government had started to modernize Whitehall. It was also intended that the regional plans should reflect regional needs, views and experience, and advisory regional councils would be set up with membership drawn from industry, local authorities, the universities, commerce and others concerned with strengthening and improving the fabric of regional life. These councils, to which the Government would look for considered and informed advice on regional problems, would participate in the examination and analysis which should precede sensible planning decisions and would work with regional planning boards consisting of representatives of the main social and economic departments. The chairmen of these boards would be appointed by the Secretary of State for Economic Affairs and each regional headquarters would have staff from that Department. The Secretary of State for Scotland would set up a Scottish planning council with similar functions and membership and the Scottish Development Group would be strengthened and constituted as a Scottish planning board. Similar arrangements would be made for Wales.

The resumed debate in the House of Commons on November 5 was concerned with technology. In opening the debate, Mr. Q. Hogg criticized particularly the decision to separate industrial and academic science as seen in the establishmont of a Ministry of Technology and the Secretary of State for Education and Science. Mr. M. Stewart, who followed, pointed out that the previous Government had itself proposed to place the National Research Development Corporation with the Board of Trade, and went on to outline the new structure of the Department of Education and Science. This Department would include the Medical, the Agricultural and the new Science Research Councils. Some of the functions of the Department of Scientific and Industrial Research would be transferred to the new Science Research Council, which would also have responsibilities relating to the European Space Research Organization. A new National Environment Research Council would be established to bring together the activities of the Nature Conservancy, the Geological Survey and other groups of study including oceanography. There would also be the Advisory Council for Scientific Policy, responsible, inter alia, for advising the Secretary of State on the allocation of resources between different fields of research.

The Ministry of Technology would assume tho responsibility for the Atomic Energy Authority, the industrial side of the Department of Industrial and Scientific Research and the work now being done by the National Research Development Corporation. On the dissolution of the Department of Scientific and Industrial Research, Mr. Stewart pointed out that this was part of the previous Government's proposals, and although he did not refer to tho Trend Report, as did Mr. E. Lubbock later in the debate, he did refer to the wide consultations between the late Government and all concerned with the proposed reorganization. He referred to the criticisms voiced by the Institution of Professional Civil Servants, though he did not point out as he might well have done, in view 
of the extent to which the present proposals follow those of the Trend Report, that the demand for fresh consultation is largely specious. A government must take its own decisions once it is satisfied it has ascertained the facts and the views of those concerned. As to the status of members of the Institution under the new arrangemonts, he readily agreed as to the desirability of full consultation

In reply to specific questions, Mr. Stewart said that no decision had yet been taken regarding the National Physical Laboratory or as to whether there would be any change in the organization of the Atomic Energy Authority. He would not say yet whether the Committee on Scientific Manpower would continue as at present or whether separate committees would deal with technological and with scientific manpower. This was a matter which the Department of Education and Science and the Ministry of Technology would have to consider jointly. The Ministry of Technology would also be concerned with the development in the civilian field of the kind of research and development contract familiar in the field of defence. There would also be an Advisory Council on Technology with the Minister as chairman and Prof. P. M. S. Blackett as deputy chairman (see also p. 922 of this issue of Nature). Finally, thore was a need to take a broader view of the educational process. It was necessary not only to provide a sufficient amount of skilled manpower but also to achieve in the population as a whole a general understanding of what a technological civilization meant.

This explanation of the Government's proposals was welcomed in a particularly well-informed speech by $\mathrm{Mr}$. E. Lubbock, who asked what would be the role of the new Council of Engineering Institutions and whether they would be represented on the new Advisory Council: he thought it might well be a valuable source of advice. Otherwise there was little constructive comment in the debate, the main other topic being the future of the Concord project. This was raised by Mr. Lubbock and other speakers in relation to its effect on Britain's technology generally, and although it was originally raised by Mr. Q. Hogg, who also asked about Britain's support of the European Launcher Development Organization and the European Space Research Organization, Mr. Stewart left it to the Minister of Aviation, Mr. R. Jenkins, to reply in winding up the debate.

Sir Lionel Heald, who stressed the importance of the aircraft industry in Britain's technology, quoted Sir George Edwards's opinion that Concord represented the first full collaboration in such a venture by two groat European powers and that it might be the first step to a world rationalization of the civil aviation effort. He was concerned as to the effect of discontinuing the Concord project on the other collaborative projects. Mr. N. Marten, liko Mr. A. Neave and many others, was concerned about the future of the design teams and other workers in the industry if the project was discontinued. Mr. E. S. Bishop's concern that public expenditure on research and development should be well spent and not wasted was also generally shared.

Dr. J. Bray questioned whether discontinuance of the Concord project would, in fact, lead to a considerable loss of skilled manpower to the United States, and pointed out that the maximum number of workers who might be redundant by the end of 1965 was 6,000 . Strong support for the project came from Mr. Angus Maude, who was convinced that supersonic transport was bound to come, but very reasonable answers were given to his specific questions by Mr. R. Jenkins in his reply on the debate. Mr. Jenkins reiterated that the only decision taken so far was to ask for an urgent review of the project, and he had personally explained to the French Minister of Transport in Paris Britain's doubts about the project. He had also had talks with the French Minister of Defence and the Minister of Science, who had French responsibility for the European Launcher Development Organization; a meeting had been arranged for January at the request of the French and Italian Governments, when the rising costs of this project and their allocation would be discussed.

As regards Concord, Mr. Jenkins said that neither Britain nor France had as yet spent or committed large sums, and up to the present time only about 3,000 people were involved, mostly in Bristol with about 400 in Coventry. The point had been reached where costs and the amount of labour involved would begin to rise fairly sharply. Besides these short-term reasons for desiring to review, there were long-term reasons. All should be satisfied that the counterbalancing technological and social considerations were commensurate with the costs. Whatever view was eventually taken of the Concord project, he was convinced that in the interests of both the French and the British aircraft industries, the two countries should work as closely as possibie alongside each other. Collaboration so far had been happy and our doubts were entirely about the Concord project, not the collaboration. If the Government was convinced that the project was in the best interests of both countries it would wish it to go ahead, and even if there was an area of legitimate doubt a solution might still be found which would retain the possibility of developing a supersonic airliner which would be economic. But it could not be assumed that Britain's scarco resources permitted her to develop every existing possibility.

\section{SCIENTIFIC RESEARCH IN SCHOOLS}

T HE president of the Royal Society, Sir Howard Florey, presided at a meeting in the Society's apartments at Burlington House, London, W.1, on September 30 , to hear an account of some of the researches which have been carried out by practising teachers assisted by funds administered by the society's Research in Schools Committee.

The president, in his introductory remarks to an audience of more than 140 comprising school science teachers, their research advisers and officials of tho Association for Science Education, said that the Council and Fellows take a great pride in the work done in schools, with the holp of the committee, and it is crucial to Britain's benefit for this kind of work to be undertaken in schools. In addition, it gives teachers an insight into the frustration and disappointment which often go hand in hand with research.

After the president's remarks two papers were read, followed by a discussion and an interval for tea. Then two further papers were read and a further discussion was held. A brief summary of the four papers is given here. Studies of Sympatric Evolution in the Butterfy, Maniola jurtina. By W. H. Dowdeswell, Winchester College.

The number of spots on the underside of the hind-wings of the meadow brown butterfly (Maniola jurtina) was a characteristic well known to be subject to the action of natural selection. Among the females, a typical South European spot-distribution with a high mode at 0 spots changed abruptly to a bimodal distribution (at 0 and 2 spots) in the vicinity of the Devon-Cornwall border where no physical barriers exist which might restrict the flight of the insect. There was evidence that the braconid Apanteles tetricus may be one of the agents tending to reduce spotting, while the bacterium Pseudomonas fuorescens may have the opposite effect. We might have a situation here comparable with that controlling sicklecell anæmia in man. 